\title{
PEMBUATAN ZIRKON TETRAKLORIDA DARI PASIR ZIRKON DENGAN PROSES KERING SECARA LANGSUNG
}

\author{
Budi Sulistyo \\ Bidang Kimia dan Proses Bahan, PTAPB, BATAN, YOGYAKARTA
}

\begin{abstract}
ABSTRAK
PEMBUATAN ZIRKON TETRAKLORIDA DARI PASIR ZIRKON DENGAN PROSES KERING SECARA LANGSUNG. Logam zirkon diperlukan sebagai bahan struktur pada kelongsong bahan bakar reaktor nuklir, bejana tekan dan pipa maupun sebagai paduan logam zirkon yang mendukung industri nuklir dan nonnuklir. Pengolahan pasir zirkon dilakukan tiga tahapan proses yaitu tahap I : memisahkan antara unsur zirkonium dengan unsur silikon, diperoleh hasil $\mathrm{ZrCl}_{4}$ dan hasil samping $\mathrm{SiCl}_{4}$, tahap II : proses pemurnian $\mathrm{ZrO}_{2}$, dan tahap III : proses pembuatan logam zirkon dari $\mathrm{ZrO}_{2}$. Pada tahap I ini ada dua proses yaitu proses basah dan proses kering. Pada proses kering ada 3 cara, yaitu proses karbida, proses karbonitrit dan proses kering secara langsung. Dari ketiga cara proses kering tersebut ada perbedaan mendasar, yaitu tingkat suhu operasinya yang berakibat pada derajat konversi proses. Pada penelitian ini yang dilakukan adalah proses kering secara langsung karena suhunya paling rendah di antara proses kering lainnya. Metode yang digunakan dalam proses kering secara langsung ini adalah fixed bed chlorination. Tujuan penelitian ini adalah untuk mempelajari pengaruh perbandingan pasir zirkon dengan karbon, pengaruh jumlah gas $\mathrm{Cl}_{2}$ dan pengaruh pembuatan umpan, terhadap konversi zirkon tetraklorida. Zirkon tetraklorida adalah hasil antara dari pengolahan pasir zirkon menjadi zirkon ingot, yang dapat digunakan sebagai bahan dasar pembuatan $\mathrm{ZrO}_{2}$, dan atau logam zirkon. Sebagai bahan baku adalah pasir zirkon dengan kadar $45 \%$ berat $\mathrm{Zr}$ dan karbon dari calsined coke atau grafit, gas $\mathrm{Cl}_{2}$ serta sukrosa sebagai binder. Pasir zirkon dan karbon terlebih dulu dibentuk briket, baru kemudian dilakukan klorinasi pada suhu $950^{\circ} \mathrm{C}$ dengan waktu 15 menit, tekanan $74 \mathrm{mmHg}$. Hasil klorinasi adalah $\mathrm{ZrCl}_{4}$ dan $\mathrm{SiCl}_{4}$. Dari penelitian ini diperoleh perbandingan berat umpan pasir zirkon : karbon : sukrosa adalah $73: 22: 5 \%$ berat, tekanan pembriketan $18 \mathrm{kN}$, kecepatan alir gas $\mathrm{Cl}_{2} 4,4$ l/menit, diperoleh konversi klorinasi sebesar $17 \%$.
\end{abstract}

\begin{abstract}
PRODUCTION OF ZIRCONIUM TETRACHLORIDE FROM ZIRCONIUM SAND BY DIRECT DRY PROCESS. The zircon metal is needed for cladding of nuclear reactor fuel, pressure vessel and pipe or its alloy for supporting nuclear and also non nuclear industry. There are three process steps, the first is separation of Si from Zr, obtained result of $\mathrm{ZrCl}_{4}$ and $\mathrm{SiCl}_{4}$ as side product, the second is purification of $\mathrm{ZrO}_{2}$ and third is the production of zircon metal from $\mathrm{ZrO}_{2}$. For the first step there are wet process and dry process. The dry process has three methods, carbide process, carbonitride process and direct process. The difference of the three methods is temperature of operation that give effect in the conversion rate. In this reasearch, the direct dry process was conducted because the temperature requirement is the lowest of the two. Fixed bed chlorination was choosen for direct by process. The aim of the research is to study the effect of feed ratio and flow rate of $\mathrm{Cl}_{2}$ on the conversion of zircon tetra chloride. Zircon tetrachloride, which was the medle product of zircon sand processing, can be used as raw material for getty $\mathrm{ZrO}_{2}$ or and zircon alloy. As the raw materials is zircon sand at the concentration of $45 \% \mathrm{Zr}$, carbon from calcined coke or graffit, $\mathrm{Cl}_{2}$ gas and sucrose as binder. Zircon sand and carbon were briqueted, and then chlorinated at $950^{\circ} \mathrm{C}$ for 15 minutes at the pressure of $74 \mathrm{mmHg}$. The chlorinated result are $\mathrm{ZrCl}_{4}$ and $\mathrm{SiCl}_{4}$. The result obtained are the percentage weight ratio of zirconium sand feed, carbon and sucrose is $73: 22: 5 \%$ weight, the briquette pressure 18 $\mathrm{kN}$, the flow rate of $\mathrm{Cl}_{2} 4.4 \mathrm{l} /$ minute, and the chlorination conversion is $17 \%$.
\end{abstract}

\section{PENDAHULUAN}

7 irkonium banyak didapatkan pada batuan vulkanik, basalt dan granit. Mineral baddeleyit atau $\mathrm{ZrO}_{2}$ adalah bentuk dari zirkonium dioksida alam. Kristalnya mempunyai densitas antara 5,4-6,02 g/cc dan kekerasan 6,5 skala Moh's. Dalam jumlah sedikit, zirkonium banyak terdapat pada mineral titanat, tantalo viobat, tanah jarang dan silikat. Zirkonium terdapat dalam campuran antara mineral baddeleyit (kandungan $67,2 \%$ berat $\mathrm{ZrO}_{2}$ dan $30,1 \%$ berat $\mathrm{SiO}_{2}$, dan hafnium sekitar $\left.2 \%\right)$ dengan zirkon silikat $\left(\mathrm{ZrSiO}_{4}\right)$ yang memenuhi syarat untuk dikomersialkan ${ }^{[1,2,3]}$. Zirkonium hanya dapat membentuk satu oksida yaitu $\mathrm{ZrO}_{2}$ yang bersifat amfoter. Garam- 
garam zirkonium normal, seperti $\mathrm{ZrCl}_{4}$ mudah terhidrolisis dalam larutan, terutama menimbulkan garam-garam zirkonil yang mengandung radikal bivalen $\mathrm{ZrO}_{2}$. Pada suhu tinggi zirkonium dapat bereaksi dengan oksigen, nitrogen, halogen, sulfur, hidrogen maupun karbon. Zirkonium hasil pengolahan dari pasir zirkon dalam pemanfaatannya dipadu dengan unsur-unsur logam lain. Paduan logam zirkonium ini disebut zircalloy $y^{[1,2,3]}$. Logam zirkonium merupakan bahan yang strategis baik dalam teknologi nuklir maupun bidang industri nonnuklir. Kegunaan logam zirkonium dalam industri nuklir adalah sebagai bahan kelongsong bahan bakar reaktor dan struktur.

\section{Sifat logam zirkonium}

1. Zirkonium mempunyai sifat tahan terhadap korosi pada suhu tinggi, sehingga zirkonium berfungsi sebagai pelindung bahan bakar reaktor nuklir ${ }^{[4]}$.

2. Zirkonium mempunyai tampang lintang serapan terhadap neutron termal yang sangat rendah $(0,18-0,2$ barn). Karakteristik ini dapat dipenuhi oleh alumunium (0,23 barn) maupun magnesium (0,063 barn), namun alumunium dan magnesium hanya untuk reaktor suhu rendah saja, misalnya untuk reaktor riset, karena pada suhu tinggi ketahanan terhadap korosi menurun.

3. Zirkonium merupakan logam yang mempunyai ketahanan korosi yang besar, baik terhadap berbagai konsentrasi asam maupun basa, dan pada berbagai suhu.

4. Logam zirkonium mempunyai titik leleh yang tinggi dan mempunyai sifat mudah dibentuk.

\section{TEORI}

Dalam pembuatan logam zirkonium dari pasir zirkon, pada tahap I diperoleh zirkon tetraklorida, yang merupakan hasil sementara, lalu diubah menjadi $\mathrm{ZrO}_{2}$, kemudian menjadi logam zirkon. Selain itu diperoleh juga hasil samping berupa $\mathrm{SiCl}_{4}$, sebesar $15 \%$ berat $\mathrm{Si}$, dan hafnium sekitar $2 \%$. Pada tahap I ini ada dua macam proses yaitu proses basah dan proses kering. Proses basah relatif mudah tetapi jalannya lebih panjang, memerlukan banyak bahan kimia dan hasil limbahnya banyak. Proses kering, prosesnya agak sukar karena menggunakan suhu tinggi, tetapi jalannya singkat, penggunaan bahan kimia dan limbah yang dihasilkan relatif lebih sedikit.

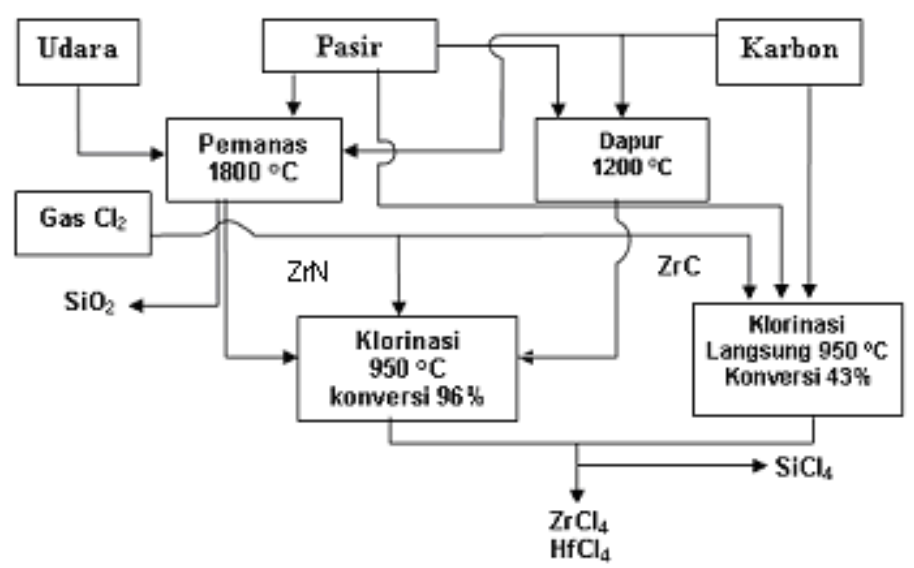

Gambar 1. Blok diagram proses kering pembuatan $\mathrm{ZrCl}_{4}$ dari pasir zirkon

Proses kering dibagi dua macam yaitu kering tidak langsung dan kering langsung. Pada proses kering tidak langsung dilakukan pemanasan campuran pasir dan karbon pada suhu tinggi untuk memisahkan silikonnya, kemudian dilakukan proses klorinasi menghasilkan $\mathrm{ZrCl}_{4}$. Pada proses kering langsung adalah proses pemanasan campuran pasir zirkon dengan karbon dan sekaligus proses klorinasi sehingga menghasilkan $\mathrm{ZrCl}_{4}$ dan $\mathrm{SiCl}_{4}$ dan sedikit $\mathrm{HfCl}_{4}$. Proses kering tidak langsung dibagi dua yaitu proses karbida, dan proses karbonitrit. Ketiga proses kering tersebut yang berbeda pada suhu pemanasannya, semakin tinggi suhu pemanasannya konversi hasilnya semakin tinggi. Proses karbonitrit, suhu pemanasannya paling tinggi di atas $1200{ }^{\circ} \mathrm{C}$ karena perlu panas untuk membentuk senyawa ZrC (Zirkon Carbida) atau ZrN (Zirkon Nitrida). Konversi hasil paling 
tinggi sekitar $96 \%$, sedangkan proses kering langsung, suhu pemanasan lebih rendah $\left(950^{\circ} \mathrm{C}\right)$ dan konversi hasil juga lebih rendah yaitu $43 \%^{[1,2]}$.

\section{Proses kering langsung}

Pembuatan zirkon tetraklorida dari pasir zirkon dengan proses klorinasi langsung, dilakukan dengan mencampur pasir zirkon, karbon atau grafit dengan perbandingan tertentu. Campuran tersebut dipanaskan pada suhu tinggi, dan dialiri gas $\mathrm{Cl}_{2}$, diperoleh hasil $\mathrm{ZrCl}_{4}$ dan $\mathrm{SiCl}_{4}$ dan gas $\mathrm{CO}$. Reaksi yang terjadi adalah sebagai berikut :

$$
\mathrm{ZrSiO}_{4(\mathrm{~s})}+4 \mathrm{C}_{(\mathrm{s})}+4 \mathrm{Cl}_{2(\mathrm{~g})} \rightarrow \mathrm{ZrCl}_{4(g)}+\mathrm{SiCl}_{4(g)}+4 \mathrm{CO}_{(g)}
$$

Pasir zirkon mempunyai bentuk senyawa $\mathrm{ZrSiO}_{4}$, ketiga unsur tersebut mempunyai ikatan atom yang sangat kuat sehingga untuk memecah ikatan tersebut dibutuhkan energi yang besar dan juga reduktor yang kuat. Pada pelaksanaan dalam proses, dipanaskan pada suhu tinggi $\left(950^{\circ} \mathrm{C}\right)$ dan diperlukan karbon $(\mathrm{C})$ sebagai reduktor. Setelah ketiga ikatan tersebut pecah, maka direaksikan dengan gas $\mathrm{Cl}_{2}$, sehingga $\mathrm{Zr}$ dan $\mathrm{Si}$ bereaksi dengan gas $\mathrm{Cl}_{2}$, membentuk senyawa $\mathrm{ZrCl}_{4}$ berwarna kuning dan $\mathrm{SiCl}_{4}$ berwarna putih. Kedua senyawa dapat dipisahkan secara fisika karena perbedaan suhu sublimasinya. $\mathrm{ZrCl}_{4}$ suhu sublimasinya adalah $331{ }^{\circ} \mathrm{C}$, sedangkan $\mathrm{SiCl}_{4}$ suhu sublimasinya $150{ }^{\circ} \mathrm{C}$. Unsur $\mathrm{O}$ dan $\mathrm{C}$ bergabung menjadi $\mathrm{CO}$, yang berupa gas. Biasanya hasil $\mathrm{ZrCl}_{4}$ tercampur dengan $\mathrm{HfCl}_{4}$ dengan kadar $\mathrm{Hf}$ sekitar 2-5\%. Kedua campuran tersebut dapat dipisahkan dengan pemurnian secara kimia maupun fisika.

$\mathrm{ZrSiO}_{4}$ berbentuk pasir yang mempunyai berat jenis $7 \mathrm{~g} / \mathrm{cc}$, sedangkan karbon berbentuk serbuk yang mempunyai berat jenis $1,5 \mathrm{~g} / \mathrm{cc}$. Kedua bahan tersebut dicampur sampai rata. Bila kedua bahan tersebut langsung direaksikan dengan gas $\mathrm{Cl}_{2}$ yang mempunyai tekanan di atas tekanan atmosfir, maka karbon akan terhembus lebih dahulu, sehingga reaksi reduksi tidak bisa berjalan dengan baik, yang akhirnya gas $\mathrm{Cl}_{2}$ tidak bisa bereaksi dengan $\mathrm{Zr}$ maupun $\mathrm{Si}$. Supaya klorinasi berjalan dengan baik maka campuran yang berbentuk serbuk dipadatkan dengan cara dibuat pelet atau dibriket atau dibuat bentuk butir dengan ukuran dan kekerasan tertentu. Untuk dapat berbentuk briket maupun butir diperlukan perekat. Sebagai perekat biasanya dipilih sukrosa karena dapat merekat pada suhu di atas $300^{\circ} \mathrm{C}$ dan tidak menambah pengotor, bahkan menambah karbon. Tujuan pembriketan adalah untuk memadatkan campuran yang berasal dari beberapa serbuk menjadi bentuk padatan dengan ukuran lebih besar dan kuat, mempunyai kekuatan dan porositas tertentu, sehingga tidak mudah hancur dan mudah dilalui gas $\mathrm{Cl}_{2}$.

Pada pembuatan zirkon tetraklorida dari pasir zirkon dengan proses klorinasi langsung, banyak faktor yang berpengaruh antara lain ${ }^{[8,9]}$

a. Pembuatan briket dipengaruhi oleh besar butir pasir dan karbon, jenis karbon, perbandingan campuran (pasir : karbon : sukrosa), air yang ditambahkan, ukuran briket, tekanan pembriketan, waktu, suhu pemanggangan dan ukuran briket.

b. Proses klorinasi dipengaruhi oleh suhu, tekanan, waktu, kecepatan aliran gas $\mathrm{Cl}_{2}$, tinggi bed dan perbandingan bahan dengan gas $\mathrm{Cl}_{2}$.

Pada penelitian akan dilakukan pembuatan zirkon tetraklorida dengan proses kering secara langsung dengan melihat pengaruh perbandingan umpan, kecepatan alir gas $\mathrm{Cl}_{2}$, tekanan pembriketan, jenis karbon dan jumlah bahan terhadap konversi klorinasi.

\section{Hipotesis}

Hasil zirkon tetraklorida dari pasir zirkon yang di klorinasi langsung akan besar bila jumlah karbon yang ditambahkan semakin besar atau perbandingan pasir zirkon : karbon yang semakin kecil, demikian juga dengan pemberian gas $\mathrm{Cl}_{2}$ yang lebih besar dari kebutuhan stochiometri. 


\section{TATA KERJA}

\section{Bahan yang digunakan :}

Pasir zirkon berasal dari pulau Bangka mempunyai kadar $45 \%$ berat $\mathrm{Zr}$ dan berat jenisnya $7,5 \mathrm{~g} / \mathrm{cc}$. Karbon dari petroleum coke, calsined coke dan grafit, bahan perekat sukrosa, dan gas $\mathrm{Cl}_{2}$ teknis buatan pabrik Soda Waru, Surabaya.

\section{Cara kerja}

\section{Pembuatan briket}

Pembuatan larutan sukrosa jenuh dilakukan dengan cara menimbang kristal sukrosa sebanyak 10 gram, kemudian dilarutkan dalam air sampai larutan menjadi jenuh. Pembuatan briket dilakukan dengan cara mencampur pasir zirkon, karbon dan sukrosa dengan perbandingan $73: 22: 5 \%$, sebanyak 20 gram. Pasir zirkon dan karbon dicampur sampai homogen, kemudian ditambah larutan sukrosa jenuh dan diaduk sampai rata. Campuran tersebut diambil $1 \mathrm{gram}$, kemudian dicetak dengan tekanan $18 \mathrm{kN}$ (kilonewton). Hasil cetakan berupa briket, kemudian dipanggang pada suhu $300-350{ }^{\circ} \mathrm{C}$, selama 10 menit, yang ditandai dengan sukrosa meleleh, artinya sukrosa tersebut sudah menjadi perekat, menjadi briket yang kuat tidak mudah hancur. Briket yang dihasilkan mempunyai sifat keras, porous, tidak mudah hancur dan mudah dilalui gas $\mathrm{Cl}_{2}$.

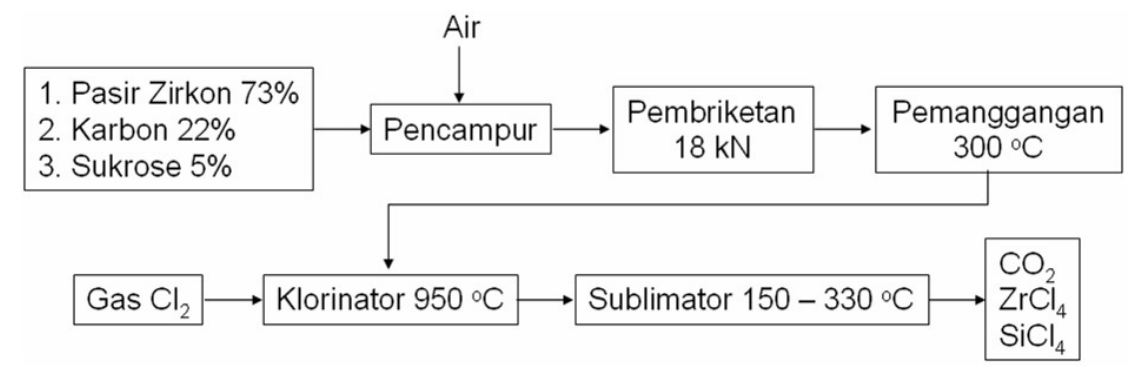

Gambar 2. Blok diagram pembuatan $\mathrm{ZrCl}_{4}$ dari briket pasir zirkon

\section{Klorinasi briket pasir zirkon}

Proses klorinasi briket pasir zirkon dilakukan dengan menggunakan peralatan klorinasi seperti yang ditampilkkan pada Gambar 3.

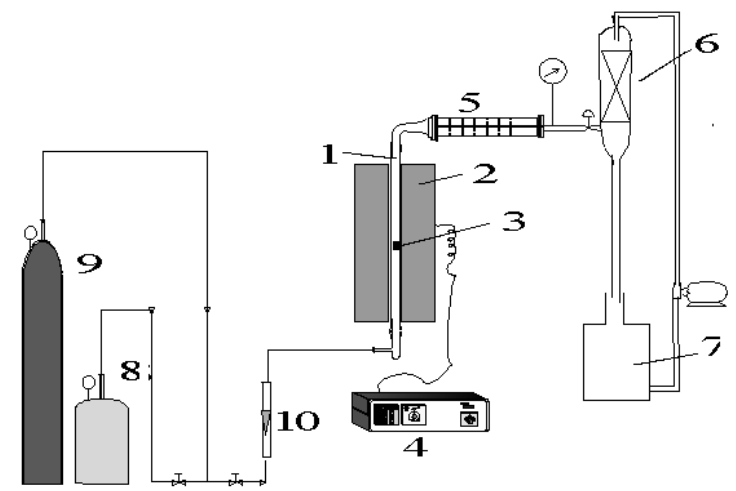

Gambar 3. Alat klorinasi pasir zirkon keterangan gambar :
1. Reaktor
2. Pemanas
3. Tempat sampel
6. Penyerap gas
4. Pengatur suhu
7. Penampung larutan penyerap gas
5. Sublimator
9. Tabung gas inert
10. Flowmeter 
Sebanyak 10 gram briket diletakkan dalam wadah dari gelas kuarsa yang tahan suhu $1200^{\circ} \mathrm{C}$, dengan ukuran diameter 1 inci dan tinggi 3 inci. Wadah kemudian dimasukkan dalam reaktor terbuat dari gelas kuarsa, tepat pada bagian tengah reaktor. Reaktor bagian atas dihubungkan dengan sublimator. Bagian bawah reaktor ditutup dan diberi lobang untuk mendistribusikan gas $\mathrm{Cl}_{2}$ dan gas inert sehingga kontak gas dan briket lebih efektif. Penyerap gas dihubungkan seri dengan sublimator. Pada penyerap gas dimasukkan larutan $\mathrm{NaOH} 2 \mathrm{~N}$ yang disirkulasi selama percobaan dengan pompa multifix. Setelah pemanasan mencapai suhu $950{ }^{\circ} \mathrm{C}, \mathrm{gas} \mathrm{Cl}_{2}$ mulai dialirkan dengan kecepatan pada skala 30 (2,12 I/menit), selama 15 menit. Gas berwarna kuning yang terbentuk mengalir ke atas masuk ke sublimator dan terdesublimasi pada suhu $331^{\circ} \mathrm{C}$. Gas warna kuning ini terdesublimasi lebih awal, sedangkan gas warna putih menyublim paling akhir karena suhu sublimasi lebih rendah kira-kira $150^{\circ} \mathrm{C}$. Gas CO masuk ke dalam penyerap gas. Setelah tidak terbentuk gas lagi, kira-kira 15 menit, percobaan dihentikan. Aliran gas $\mathrm{Cl}_{2}$ ditutup dan diganti gas inert, dialirkan beberapa menit, kemudian pemanas dimatikan. Setelah dingin tutup bagian bawah reaktor dibuka dan bahan yang tidak bereaksi dikeluarkan. Padatan warna kuning terletak pada ujung dari sublimator, sedangkan gas warna putih menyublim pada akhir tempat sublimator, kedua bahan tersebut diambil lalu ditimbang dan dianalisis kadar zirkonium dan silikonnya dengan alat spektrometer pendar sinar $\mathrm{x}$ dan APNC.

\section{HASIL DAN PEMBAHASAN}

\section{Variasi perbandingan berat pasir zirkon dengan karbon}

Pada penelitian ini, bahan utama berupa pasir zirkon, karbon dan sukrosa. Pada variasi perbandingan antara pasir zirkon dengan karbon ditentukan, sebesar 0,26 sampai dengan 0,33. Sukrosa sebagai bahan perekat ditentukan seberat $5 \%$ berat dari kedua bahan tersebut. Tekanan pembriketan $18 \mathrm{kN}$, suhu klorinasi 950 ${ }^{\circ} \mathrm{C}$, kecepatan alir gas $\mathrm{Cl}_{2} 4,41 \mathrm{l} / \mathrm{jam}$, waktu klorinasi 15 menit. Jenis karbon yang digunakan adalah petroleum coke. Perbandingan umpan, karbon : pasir zirkon divariasi mulai dari 0,26 sampai dengan 0,33 bagian. Dari Gambar 4 terlihat bahwa pada perbandingan berat karbon dengan pasir zirkon sebesar 0,26 konversi klorinasi baru mencapai $13,5 \%$. Proses klorinasi dengan perbandingan berat karbon dan pasir zirkon dinaikkan, diperoleh konversi klorinasi bertambah. Pada perbandingan karbon dengan pasir zirkon sebesar 0,33 bagian diperoleh konversi klorinasi sebesar $17 \%$. Untuk perbandingan karbon dan pasir zirkon di atas 0,33 terlihat relatif tetap (kenaikan tidak terlalu drastis). Dari hasil percobaan ini diambil perbandingan 0,33 yang memberikan hasil terbaik, yaitu $17 \%$. Karbon dalam penelitian ini berfungsi sebagai reduktor untuk memisahkan silikon dan zirkon. $\mathrm{Gas}_{2} \mathrm{Cl}_{2}$ sebagai pereaksi pembentuk $\mathrm{ZrCl}_{4}$ dan $\mathrm{SiCl}_{4}$. Reaksi klorinasi zirkon maupun silikon terjadi serentak dalam reaktor klorinasi. Hasil klorinasi berupa zirkon tetraklorida dan silikon tetraklorida yang keluar dari reaktor berbentuk gas. $\mathrm{ZrCl}_{4}$ akan terdesublimasi dalam sublimator pada suhu $331{ }^{\circ} \mathrm{C}$, sedangkan $\mathrm{SiCl}_{4}$ akan terdesublimasi dalam sublimator berikutnya pada suhu $150{ }^{\circ} \mathrm{C}$. Alat sublimasi dibuat bentuk tabung kaca mendatar, maka $\mathrm{ZrCl}_{4}$ menyublim diujung atau paling awal, sedangkan $\mathrm{SiCl}_{4}$ terdesublimasi paling akhir pada sublimator sehingga hampir terpisah.

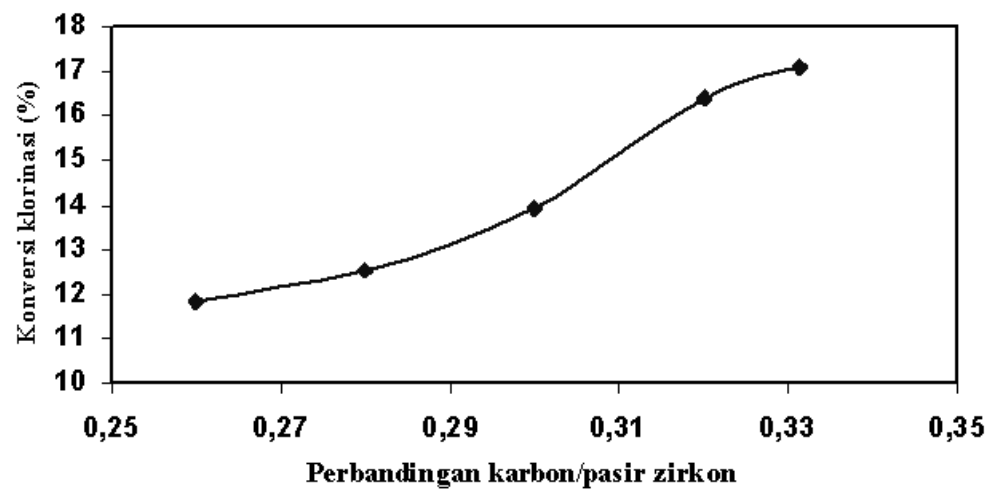

Gambar 4. Grafik hubungan perbandingan karbon/pasir zirkon terhadap konversi klorinasi 


\section{Variasi jenis dan berat karbon}

Pada penelitian ini digunakan tiga jenis karbon yaitu karbon dari batu bara, karbon aktif dan calsined coke. Pada variasi perbandingan pasir zirkon dengan karbon diulang lagi, hanya karbonnya divariasi jenisnya, yaitu batu bara, calsined coke, dan grafit. Tekanan pengepresan $18 \mathrm{kN}$, suhu $950^{\circ} \mathrm{C}$, kecepatan alir gas $\mathrm{Cl}_{2} 4,41$ liter/jam dan waktu klorinasi 15 menit. Pada Gambar 5 terlihat bahwa pada perbandingan berat karbon dengan pasir zirkon 0,29 diperoleh konversi klorinasi sekitar 11,0\%, dengan bertambahnya perbandingan berat karbon dengan pasir zirkon maka konversi klorinasi juga meningkat. Jumlah perbandingan berat karbon dengan pasir zirkon mencapai 0,33 , konversi klorinasi mencapai $17,2 \%$. Karbon dari batu bara dan calsined coke, konversi klorinasinya dapat mencapai 15,5 sampai $16 \%$, sedangkan penggunakan bahan grafit konversinya dapat mencapai $17,2 \%$, lebih besar dari batu bara maupun calsined coke, hasilnya berwarna kuning bersih, yang berarti paling baik dibanding lainya. Hasil konversi yang diperoleh sebesar $17,2 \%$ ini lebih kecil dibandingkan hasil yang dikemukakan oleh Lustman dan Miller ${ }^{[1,2]}$, hal ini disebabkan bahan yang digunakan juga berbeda. Pada penelitian ini digunakan pasir zirkon dari PT Tambang Timah yang kadar zirkonnya $<45 \%$ sehingga dalam proses khlorinasi banyak mengalami kendala oleh unsur Si yang banyak terkandung dalam pasir yang akhirnya menurunkan nilai konversi.

Karbon yang baik adalah yang mempunyai fixed carbon yang tinggi di atas $95 \%$, zat volatile, kadar abu dan uap air yang paling rendah di bawah $1 \%$. Dipilih harga karbon yang murah dan mudah didapat. Berdasarkan kajian ini maka karbon dari grafit memenuhi syarat sebagai reduktor pada proses klorinasi ini.

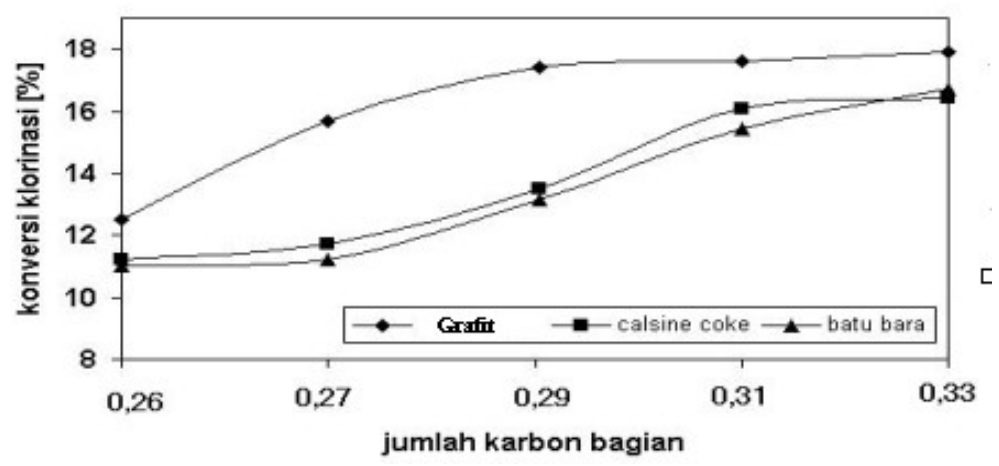

Gambar 5. Hubungan variasi jenis dan berat karbon terhadap konversi klorinasi

\section{Variasi tekanan pembriketan}

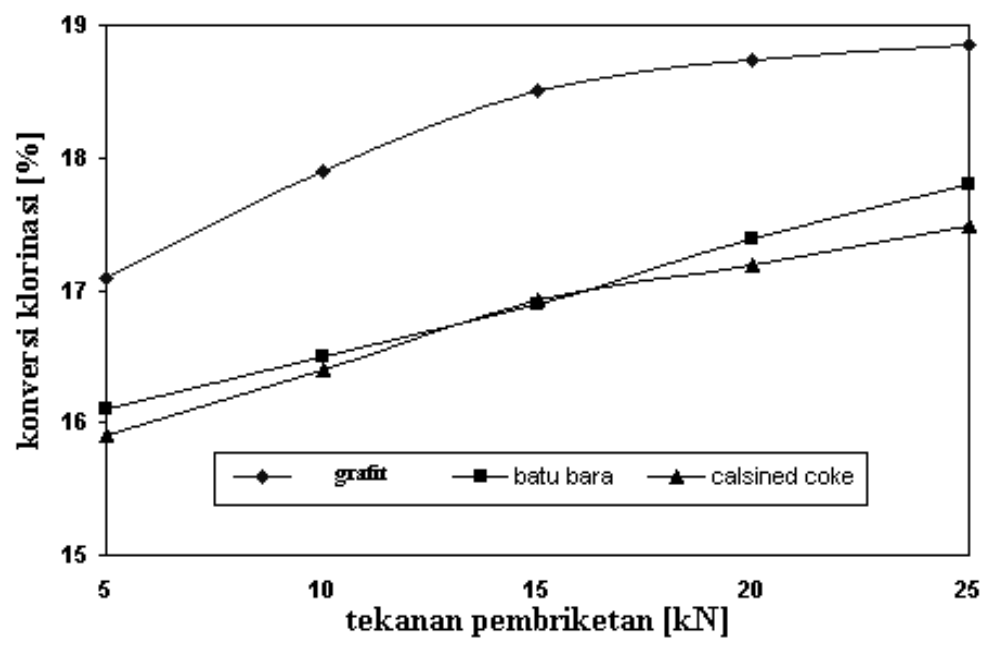

Gambar 6. Hubungan variasi tekanan pembriketan terhadap konversi klorinasi 
Pada variasi tekanan pembriketan ini, ditetapkan perbandingan pasir zirkon : karbon : sukrosa adalah 73 : 22 : 5. Kecepatan aliran gas $\mathrm{Cl}_{2}, 4,41 \mathrm{l} /$ menit, waktu klorinasi 15 menit, suhu $950{ }^{\circ} \mathrm{C}$ dan jenis karbon dari calsined coke. Tekanan pembuatan pelet divariasi mulai dari 5 sampai $25 \mathrm{kN}$. Percobaan menggunakan tiga jenis karbon, yaitu grafit, calsined coke dan batu bara. Pada Gambar 6 terlihat bahwa untuk karbon dari batu bara dan calsined coke pada tekanan pembriketan $5 \mathrm{kN}$ menghasilkan konversi klorinasi mencapai 16,7\%, dan pada tekanan $25 \mathrm{kN}$, konversi klorinasi naik menjadi $17,2 \%$. Terlihat juga bahwa reduktor grafit konversinya paling tinggi yaitu 18,9\%, dibandingkan karbon dari batu bara maupun calsined coke sekitar 17,2\%. Tekanan makin tinggi bentuk briket makin mampat atau rapat, pori-porinya semakin kecil, sehingga sukar dilalui gas $\mathrm{Cl}_{2}$. Pada briket yang mampat reaksinya hanya pada permukaan saja, sehingga konversi klorinasi menjadi turun. Pada penelitian ini tekanan yang paling tinggi $25 \mathrm{kN}$, tekanan pembriketan yang tinggi akan menyebabkan alat cetaknya cepat rusak. Pada penelitian dipilih tekanan $18 \mathrm{kN}$, pada tekanan ini briket sudah cukup kuat artinya tidak mudah hancur bila dipanaskan, porositas cukup besar, mudah dilalui oleh gas $\mathrm{Cl}_{2}$.

\section{Variasi kecepatan alir gas $\mathbf{C l}_{2}$ terhadap konversi klorinasi.}

Pada variasi kecepatan alir gas, ditetapkan ukuran bahan diameter $10 \mathrm{~mm}$, suhu $950^{\circ} \mathrm{C}$, waktu alir gas $\mathrm{Cl}_{2}$, 15 menit, tekanan pembriketan $18 \mathrm{kN}$, Berat bahan (umpan) $10 \mathrm{gram}$, perbandingan pasir : karbon : sukrosa adalah $72: 23: 5$. Kecepatan alir gas $\mathrm{Cl}_{2}$, divariasi mulai dari skala 20 sampai dengan 120 atau 1,516 sampai dengan 9, 519 liter/menit. Gas $\mathrm{Cl}_{2}$ sebagai pereaksi apabila jumlah yang diberikan besar akan menambah hasil $\mathrm{ZrCl}_{4}$. Dari reaksi 7 dapat dilihat secara teroritis untuk setiap $\mathrm{mol} \mathrm{ZrSiO}_{4}$ diperlukan $4 \mathrm{~mol} \mathrm{Cl}_{2}$. Gas $\mathrm{Cl}_{2}$ diperlukan sebagai pereaksi supaya membentuk $\mathrm{ZrCl}_{4}$ dan $\mathrm{SiCl}_{4}$. Dengan memberikan gas $\mathrm{Cl}_{2}$ berlebihan diharapkan zirkonium dan silikon dapat bereaksi semuanya menjadi $\mathrm{ZrCl}_{4}$ dan $\mathrm{SiCl}_{4}$. Pemanasan pada suhu tinggi memudahkan $\mathrm{Zr}$ dan Si bereaksi dengan gas $\mathrm{Cl}_{2}$, karena karbon mengambil oksigen yang terikat dengan $\mathrm{Zr}$ dan Si. Gambar 7 menunjukkan bahwa makin besar perbandingan pereaksi gas $\mathrm{Cl}_{2}$, yang diperlukan, konversi klorinasi $\mathrm{Zr}$ semakin bertambah besar. Pada kecepatan aliran gas $\mathrm{Cl}_{2}$ 1,516 liter/menit, konversi klorinasi mencapai 5,2\%. Pada kecepatan alir gas $\mathrm{Cl}_{2} 4,4$ liter/menit, konversi klorinasi mencapai $9,46 \%$, yang apabila dilanjutkan lagi dengan menaikkan kecepatan aliran gas $\mathrm{Cl}_{2}$ konversi menjadi turun. Hal ini disebabkan kecepatan alir gas $\mathrm{Cl}_{2}$ terlalu besar mengambil panas yang banyak menyebabkan suhu menjadi turun dan akibatnya konversi menjadi turun. Berdasarkan data tersebut maka kondisi yang baik, pada kecepatan alir gas $\mathrm{Cl}_{2}$ pada 4,41 liter/menit.

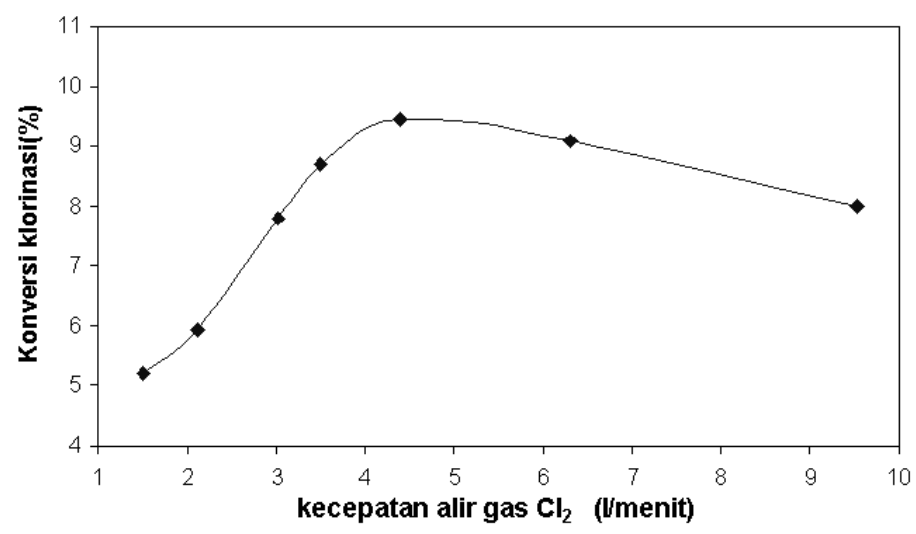

Gambar 7. Grafik hubungan kecepatan gas $\mathrm{Cl}_{2}$ terhadap konversi klorinasi

\section{KESIMPULAN}

Dari penelitian pembuatan zirkon tetraklorida yang telah dilakukan dengan menggunakan alat klorinator, maka dapat diambil kesimpulan sebagai berikut :

1. Karbon yang dapat digunakan secara efisien dan ekonomis adalah calsined coke.

2. Komposisi umpan adalah sebagai berikut : pasir zirkon $72 \%$, karbon $23 \%$, dan sukrosa $5 \%$ berat.

3. Tekanan pembuatan briket sebesar $18 \mathrm{kN}$. 
4. Kecepatan alir gas $\mathrm{Cl}_{2}$ sebesar $4,41 \mathrm{l} /$ menit.

5. Nilai konversi diperoleh sebesar $17,2 \%$ karena kadar Zr dalam pasir zirkon di bawah $45 \%$.

\section{SARAN}

Untuk menaikkan konversi proses klorinasi yang lebih besar lagi, dapat dilakukan dengan cara :

1. Menaikkan tekanan sistem.

Pada penelitian ini tekanan yang ditunjukkan manometer adalah $71 \mathrm{cmHg}$, ini adalah tekanan di bawah atmosfir. Tekanan ini dipengaruhi adanya sirkulasi larutan $\mathrm{NaOH}$ sebagai penyerap gas $\mathrm{Cl}_{2}$, akibatnya tekanan dalam sistem menjadi turun. Akibat dari hal tersebut gas $\mathrm{Cl}_{2}$ yang berdifusi dan kontak dengan briket hanya sebatas di permukaan saja. Pada tekanan tinggi gas $\mathrm{Cl}_{2}$ dapat menerobos masuk lebih jauh ke dalam briket, sehingga dapat menambah reaksi lebih sempurna, akhirnya konversi menjadi besar. Tekanan tinggi akan menaikkan jumlah mol gas $\mathrm{Cl}_{2}$. Tekanan proses tinggi kendalanya adalah pada bagian sambungan atau bagian perpak harus kuat supaya tidak mudah bocor.

2. Modifikasi alat

Modifikasi alat terutama pada bagian sublimator, perlu diberi sekat atau hambatan dan filter yang dipasang sedemikian rupa, supaya hasilnya tidak masuk dalam penyerap gas.

\section{DAFTAR PUSTAKA}

1. LUSTMAN, B. AND KERZE, F., "THE METALLURGY OF ZIRCONIUM", Mc GrawHill, Book Company Inc., New York, (1955).

2. MILLER, G.L., "The Metallurgy of Rarer Metals", Butterworths Scientific, Publications, (1957).

3. BUSRON MASDUKI, PRAMUDITA ANGGRAITA, DWIRETNANI, BUDI SULISTYO, HERRY SULISTYO, JOHNY WAHYU ADI, "Pemurnian dan Pembuatan Logam Zirkonium, Hasil dan Prospeknya di Indonesia", Prosiding Konggres IImu Pengetahuan Nasional VI, Jakarta, (1995).

4. BUDI SULISTYO, SUNARDJO, DWIRETNANI SUDJOKO, PRISTI HARTATI, "Pengaruh Kecepatan Alir Gas $\mathrm{Cl}_{2}$ dan Tinggi Bed Terhadap Hasil $\mathrm{ZrCl}_{4}$ Pada Proses Klorinasi Pasir Zirkon“, Prosiding Pertemuan dan Presentasi Ilmiah, Penelitian Dasar IImu Pengetahuan dan Teknologi Nuklir, P3TM-BATAN, Yogyakarta, (2001).

5. BUDI SULISTYO, SUNARDJO, DWIRETNANI SUDJOKO, PRISTI HARTATI.,"Pengaruh Komposisi dan Tekanan pada Pembuatan Briket Pasir Zirkon Terhadap Konversi Klorinasi", Prosiding, Pertemuan dan Presentasi IImiah, Penelitian Dasar IImu Pengetahuan dan Teknologi Nuklir, P3TM- BATAN, Yogyakarta, (2002).

6. BUDI SULISTYO, SUNARDJO, DWIRETNANI SUDJOKO, PRISTI HARTATI, "Pengaruh Jenis Karbon Pada Pembuatan Briket Pasir Zirkon Terhadap Konversi Klorinasi", Prosiding Pertemuan dan Presentasi IImiah, Penelitian Dasar IImu Pengetahuan dan Teknologi Nuklir, P3TM-BATAN, Yogyakarta, (2003). 